\title{
BETTER SAFE THAN SORRY? THE IMPACT OF THE EU-US NEGOTIATIONS UNDER TTIP ON THE REGULATION OF COSMETIC PRODUCTS
}

\author{
Elisabet Ruiz Cairo*
}

\begin{abstract}
Summary: TTIP aims at conducting a trade policy which reduces regulatory barriers. This would enable certain goods and services to move freely or more easily from the EU to the US and the other way around, resulting in gains from cost savings and efficiencies.

However, this can potentially have implications in the way risk regulation is implemented in the EU, and it has therefore raised an important debate on both sides of the Atlantic. Indeed, the United States and the European Union do not seem to share the same values in terms of risk assessment and risk management. The EU can be described as more risk averse and has developed stricter standards to address consumer health and safety or environmental issues.

This paper examines whether an EU-US trade partnership is capable of reducing regulatory barriers while safeguarding the approach towards risk regulation developed in the EU for the last two decades.
\end{abstract}

To address this topic, the paper focuses on the cosmetics sector which is of great importance in Europe since it employs large numbers of people and contributes heavily to the economy. Besides, the large regulation of the market and the high rates of trade between the EU and the US in the sector will most probably enhance the applicability of TTIP. Therefore, it is interesting to study how the negotiations on the trade agreement might impact the regulation of cosmetic products in Europe.

As an international standard hegemon in the cosmetics sector, the EU has incentivised voluntary rules in the US similar to the European ones. This will support the idea that the TTIP negotiations are not likely to modify substantially the regulatory standards set by the EU on cosmetic products because these standards are already met by an increasing number of manufacturers.

\section{Introduction}

The balance between economic gains and consumer safety is a constant debate for public authorities and it can currently be analysed upon the negotiation of the Transatlantic Trade and Investment Partnership

$\mathrm{PhD}$ candidate and Research Assistant, Centre d'Etudes Juridiques Européennes (CEJE), University of Geneva (Switzerland); elisabet.ruizcairo@unige.ch. 
(TTIP) between the EU and the US. No trade agreement has created as much debate as this one and the main concern is whether it is possible to find a balance between greater trade through measures that create economic gains and the maintenance of safety standards in the EU.

Although there is a general assumption that increasing trade between the EU and the US necessarily leads to hindering safety standards in the EU, this article will point out that trade and safety are not always incompatible goals.

In order to reach this conclusion, this article will focus on one specific area that is usually not subject to a detailed scrutiny in academic literature: cosmetics. And yet this sector is mainly composed by worldwide players which compete in a global industry where the EU is one of the leaders. Indeed, the EU market is larger than the US market and twice the size of the Japanese one. ${ }^{1}$ Moreover, negotiations over non-tariff barriers in cosmetics have raised a lot of concerns and many consumer associations, animal protection groups and other organisations have claimed that this agreement could cause great damage to the maintenance of high standards in terms of consumer safety and animal protection. ${ }^{2}$ Therefore, this sector seems particularly interesting to analyse.

The article will first confirm that negotiations on a trade agreement between the EU and the US can result in economic gains for both parties. Indeed, although tariffs between them are already very low, non-tariff barriers persist, in particular technical barriers to trade such as health and safety regulations and standards, advertising rules, and packaging and labelling regulations. TTIP would therefore facilitate the movement of goods and services between the two regions and, considering the strong trade relationship that characterises them, it would lead to cost savings and efficiencies.

Despite two ideologically opposite positions on the free trade agreement, the paper will then highlight that no race to the bottom seems to be taking place in the cosmetics sector. Indeed, it will be recalled that previous forms of cooperation have already taken place with no negative consequences on safety standards and that the EU position paper on cos-

\footnotetext{
$1 \quad$ Risk \& Policy Analysts Limited, 'Comparative Study on Cosmetics Legislation in the EU and Other Principal Markets with Special Attention to so-called Borderline Products' (2004) Final Report 3.

2 See for instance, 'TTIP Means Trading Away Better Regulation' (Euractiv, 9 April 2014) <http:/ / www.euractiv.com/sections / science-policymaking/ttip-means-trading-away-better-regulation-301454> accessed 14 December 2015; Monique Goyens, 'Cosmetic Products: What TTIP Will Not Make Up' (Bureau Européen des Unions des Consommateurs, 8 August 2014) <http://www.beuc.eu/blog/325/> accessed 14 December 2015; Emily Beament, 'TTIP: US Trade Deal Could Weaken EU Regulation' The Independent (London, 9 March 2015) <http://www.independent.co.uk/news/business/news/ttip-us-trade-deal-couldweaken-eu-regulation-10096642.html> accessed 11 April 2015.
} 
metics limits the negotiations to the least controversial areas. Further, as regards the most divergent issues, informal convergence seems to be already taking place towards European standards.

Finally, this paper will put forward that TTIP actually goes a step further in tackling regulatory challenges. It moves from the convergencedivergence scheme to propose more tailored solutions through the permanent exchange of ideas between institutions. The risks and benefits of this strategy will therefore be analysed in this final part.

\section{In the global regulatory framework of cosmetic products, can the EU benefit from the negotiations?}

\subsection{To regulate or not to regulate: that is the question}

The study of risk regulation in the EU and the US tends to follow a historical evolution because, as some authors have stated, there was a 'transatlantic shift in regulatory stringency' in the $90 \mathrm{~s}^{3}{ }^{3}$ This is apparent when looking at some of the legislative measures adopted by both regions over the last few decades.

Indeed, for about 30 years, the United States had several regulations on a wide spectrum of topics such as food, chemicals and automobiles which were among the most risk-averse in the world ${ }^{4}$ However, starting in the 90s, the EU took the lead through the adoption of higher standards pursuing health and environmental protection. ${ }^{5}$

Under this transatlantic shift lies the precautionary principle adopted by the EU in 2000 and covered by Article 191 TFEU. This core value of the European Union has been politically accepted as a risk management tool when there are reasonable grounds for concern that potential hazards may affect the environment or human, animal or plant health, and when at the same time the available data preclude a detailed risk evaluation'. ${ }^{6}$ This principle has justified large amounts of regulatory measures in the EU, whereas in the US the Supreme Court held that it cannot be regulated on the basis of mere conjecture about uncertain risks and that significant risk must be demonstrated. ${ }^{7}$

3 David Vogel, The Politics of Precaution (Princeton University Press 2012) 1-2.

4 ibid 3.

5 Theofanis Christoforou, 'The Precautionary Principle, Risk Assessment, and the Comparative Role of Science in the European Community and the US Legal System' in Vogel (n 3) 4 .

6 Commission, 'Communication on the precautionary principle' (Communication) $\operatorname{COM}(2000) 1$.

7 Jonathan B Wiener, 'Whose Precaution After All? A Comment on the Comparison and Evolution of Risk Regulatory Systems' (2003) 13 Duke Law School Public Law and Legal Theory Research Paper Series 47, 214. 
While it is interesting to analyse how risk regulation has evolved on both sides of the Atlantic, it must be stated that 'we need caution about precaution, and about comparisons of national precaution' ${ }^{8}$ Indeed, the EU seems to adopt more stringent rules when regulating consumer safety, which is the object of this paper, whereas the US has adopted more precautionary regulations on terrorism or weapons of mass destruction. ${ }^{9}$ As a consequence, it seems more appropriate to compare risk regulation in a particular sector, which is why the following paragraphs will focus on cosmetics.

\subsection{The regulation of cosmetic products as an illustration of regulatory differences}

The cosmetics sector is subject to wide differences in regulatory stringency not only between the EU and the US but all over the world. In broad terms, there are two global models to regulate cosmetics: according to the first model, a wide definition of cosmetics is adopted, ingredients are restricted through positive and negative lists and there are safety tests and data files on safety; the second model adopts a narrow definition of cosmetics, there are few restrictions on ingredients, and safety tests are determined by manufacturers. The former model is the one followed by the EU, whereas the latter is closer to that of the US. ${ }^{10}$

In the EU, cosmetic products are regulated under Regulation (EC) No $1223 / 2009 .{ }^{11}$ The sector had been regulated for years under Directive No $76 / 768 / \mathrm{EC}^{12}$ but a new regulation was adopted in 2009 and entered into force in 2013. The new regime was a recast of the former piece of legislation which had suffered a large number of amendments and had become increasingly difficult to understand.

When analysing European legislation it can be noted that there has been a progressive strengthening of consumer safety. The progressive ban on animal testing, the newly introduced labelling requirements for nanomaterials and the enlargement of the negative list annexed to the regulation illustrate this evolution. In terms of governance, risk assessment reports are prepared by the Scientific Committee on Consumer Safety, ${ }^{13}$ funded by an independent group of scientists with wide exper-

\footnotetext{
8 ibid 269.

9 See Jonathan B Wiener, The Reality of Precaution: Comparing Risk Regulation in the United States and Europe (RFF Press 2011).

10 Risk \& Policy Analysts Limited (n 1) 4.

11 Council Regulation (EC) 1223/2009 of 30 November 2009 on cosmetic products [2009] OJ L342/59 (Cosmetics Regulation).

12 Council Directive 76/768/EEC of 27 July 1976 on the approximation of the laws of the Member States relating to cosmetic products [1976] OJ L262/169.

13 Previously, Scientific Committee on Consumer Products.
} 
tise and whose evaluation is compulsory before the Commission takes a decision. ${ }^{14}$

We can therefore say that the EU has adopted an increasingly riskaverse approach as regards cosmetics safety. ${ }^{15}$

In the United States, cosmetics are regulated under the Food, Drug and Cosmetic Act of 1938 (FD\&C Act) ${ }^{16}$ which granted broad regulatory authority to the Food and Drug Administration (FDA).

One of the main differences with the EU is the definition of cosmetic products established in the US and the border between drugs and cosmetics established in that country. Indeed, according to these definitions, many cosmetics under EU law will also be defined as cosmetics under US law (such as moisturizers, perfumes or lipsticks). However, some products considered as drugs in the US will be regulated as cosmetics under EU law. This is the case of sunscreens and, in general, all 'articles intended for use in the diagnosis, cure, mitigation, treatment, or prevention of disease... and articles (other than food) intended to affect the structure or any function of the body of man or other animals'. ${ }^{17}$ Moreover, under US law there is a third category of products which are over-the-counter (OTC) drugs which are drugs that can be purchased without a doctor's prescription.

As regards animal testing, this is allowed in the US, and the FDA has consistently advised 'cosmetic manufacturers to employ whatever testing is appropriate and effective for substantiating the safety of their products' which includes animal testing when the manufacturer determines that it is 'necessary to assure the safety of a product or ingredient'. ${ }^{18}$ Although the institution recommends using alternative methods when possible and advocates the employment of the most humane methods when animal testing is the only available option, the reality is that no legislative actions have been taken to ban this practice.

Another important difference concerns the negative list of prohibited ingredients which in the US only contains 11 substances, ${ }^{19}$ whereas

\footnotetext{
14 Giulia Ciarlo, 'Le règlement de 1'Union européenne sur les "cosmétiques": 35 ans d'évolution vers une législation européenne plus claire et des produits plus sûrs' (2013) 4 Revue du Droit de 1'Union Européenne 691.

15 For a detailed analysis of the European regulation on cosmetic products, see Elisabet Ruiz Cairó, 'Le nouveau règlement n 1223/2009: la recherche d'un équilibre entre innovation et protection des consommateurs'(2015) 53 Revista Española de Derecho Europeo 113. 16 United States Code, Title 21 'Food and Drugs', Sections 1-2252 <http://www.gpo.gov/ fdsys/pkg/USCODE-2013-title21/pdf/USCODE-2013-title21.pdf> accessed 7 December 2015.

17 FD\&C Act, sec. 201(g)(1).

18 US Food and Drug Administration, 'Animal Testing \& Cosmetics' (31 May 1999) <http:// www.fda.gov/Cosmetics/ScienceResearch/ProductTesting/ucm072268.htm> accessed 7 December 2015.

19 See Food and Drug Administration < http://www.fda.gov/cosmetics/guidanceregulation/lawsregulations/ucm127406.htm> accessed 7 December 2015.
} 
the European regulation contains up to 1,328 prohibited ingredients. ${ }^{20}$ However, it has to be recalled that the 11 prohibited substances in the US only apply to cosmetics under the definition of that country. Hence, if a product is considered a drug it will be subject to pre-market approval, whereas it could still be considered a cosmetic product under European law and therefore not subject to pre-market approval there.

Finally, in terms of governance, the Cosmetics Ingredients Review board (CIR), funded by the industry trade association, reviews and assesses the safety of some ingredients and classifies them according to their known or probable risks. Yet the FDA is not obliged to act on its findings and only $11 \%$ of the ingredients found in cosmetics have been assessed for safety by the panel.

To sum up, a distinction has to be made between products that are considered cosmetics in both regions and products that are not. Indeed, the regulation of cosmetics categorised as such also in the US is quite similar in terms of producer responsibility and the absence of pre-market approval requirements, but there are significant differences concerning the regulation of the composition of the products, in particular as regards positive and negative lists of ingredients, animal testing or nanomaterials. However, the regulation of products categorised as drugs or quasi-drugs in the US is quite different in both regions as it generally implies pre-market approval and it imposes restrictions on composition and manufacturing processes in the US. ${ }^{21}$

Table 1: Regulatory differences between the EU and the US in the cosmetics sector

\begin{tabular}{|l|l|l|}
\hline & $\begin{array}{l}\text { European Union, } \\
\text { Regulation (EC) } \\
\text { No } \mathbf{1 2 2 3 / 2 0 0 9}\end{array}$ & United States, FD\&C Act \\
\hline Definition & Broad definition & $\begin{array}{l}\text { Narrow definition } \\
\text { Border cosmetics- OTC drugs }\end{array}$ \\
\hline Ingredients & $\begin{array}{l}\text { Positive and negative lists } \\
(1,378 \text { banned ingredients })\end{array}$ & Only 11 banned ingredients \\
\hline Animal testing & Completely banned & $\begin{array}{l}\text { Not banned but alternative } \\
\text { testing methods encouraged }\end{array}$ \\
\hline Nanomaterials & $\begin{array}{l}\text { Regulated (labelling) } \\
\text { SCCP: independent group of } \\
\text { scientists, systematic risk } \\
\text { assessment }\end{array}$ & $\begin{array}{l}\text { Not regulated } \\
\text { trade association, no } \\
\text { systematic assessment }\end{array}$ \\
\hline
\end{tabular}

Source: self-elaborated by the author

\footnotetext{
20 Annex II of the Cosmetics Regulation.

21 Risk \& Policy Analysts Limited (n 1) 37.
} 


\subsection{The benefits of regulatory cooperation: a stronger trade relationship}

As the previous paragraphs have made apparent, regulatory divergences between the EU and the US persist, in particular as regards cosmetics. Even though the two markets are highly integrated with quite low tariffs, there are 'behind the border' trade barriers derived from different regulatory philosophies that hinder the development of a tighter marketplace and impede market access. ${ }^{22}$ These differences are especially relevant considering the strong trade relationship built between the two regions.

The EU and the US have the largest bilateral trade relationship in the world, accounting for more than $30 \%$ of global trade in goods. They are each other's main trading partner, and the overall transatlantic workforce is estimated at 15 million workers. ${ }^{23}$ These two regions are also each other's most important source of foreign direct investment, with US investment in the EU being three times higher than in all Asia, and EU investment in the US being eight times the amount of investment in India and China together. ${ }^{24}$

As a consequence, regulatory barriers create important costs for transatlantic trade and are often considered the most significant impediment to trade and investment between the EU and the US. ${ }^{25}$ There are different ways by which costs are increased, such as double burdens as regards certifications and testing requirements and different production processes to meet the different standards. ${ }^{26}$ For instance, a requirement to change the packaging, the advertising campaign or even the composition of a product raises costs for producers and increases the time needed to introduce a product on the other side of the Atlantic. ${ }^{27}$

In the cosmetics sector, these barriers to trade are all the most significant. Indeed, the industry is mainly composed of international com-

\footnotetext{
22 Tamara Takacs, 'Transatlantic Regulatory Cooperation in Trade: Objectives, Challenges and Instruments for Economic Governance' in Elaine Fahey and Deirdre Curtin (eds), A Transatlantic Community of Law: Legal Perspectives on the Relationship between the EU and US Legal Orders (CUP 2015) 159.

23 Delegation of the European Union to the United States, 'EU-US Relations: Trade and Investment', <http:/ /www.euintheus.org/what-we-do/policy-areas/trade-investment-andbusiness/eu-us-relations-trade-and-investment/> accessed 7 December 2015.

24 European Commission, DG Trade, Countries and Regions: United States, <http:// ec.europa.eu/trade/policy/countries-and-regions/countries/united-states/> accessed 7 December 2015.

25 Takacs (n 22) 160.

26 Simon Lester and Inu Barbee, 'The Challenge of Cooperation: Regulatory Trade Barriers in the Transatlantic Trade and Investment Partnership' (2013) 16 Journal of International Economic Law 852.

27 Risk \& Policy Analysts Limited (n 1) 3.
} 
panies which represent around $80 \%$ of the production in the EU so barriers to trade have a great impact on them. Moreover, taking into account the high costs of production in this area, undertakings usually seek economies of scale by manufacturing goods that can be sold in different markets, and regulatory barriers can hinder this goal. In addition, in a very innovative area such as cosmetics, where a large number of new products are put on the market every year and where others are reformulated and replaced, regulatory constraints can also limit innovation. Indeed, they increase the costs of development of new products and delay the introduction of cosmetics on the market. ${ }^{28}$

Regulatory convergence is said to increase not only trade between the EU and the US, but also trade with third countries because many of them adopt European and American standards. ${ }^{29}$ On the other hand, regulatory barriers in the industry carry a very high cost.

In the previous paragraphs it has been acknowledged that, with the strongest trade relationship in the world, a transatlantic agreement would certainly result in economic gains due to the obstacles that regulatory divergence impose for undertakings. Although this finding is not new, the next paragraphs will put forward the view that these savings and efficiencies are not likely to lead to a race to the bottom as regards safety standards.

\section{A race to the bottom or a race to the top?}

\subsection{Previous forms of cooperation between the EU and the US}

As the literature has put forward, "TTIP is not occurring in a vacu$\mathrm{um}^{30}$ and there have been several initiatives at different levels to coordinate regulatory policies. However, up until now, regulatory cooperation between the EU and the US has taken the form of soft-law instruments such as consultations, dialogue, exchange of information or sharing of best practices, with the exception of a few mutual recognition agreements. ${ }^{31}$ Yet, there have not been any attempts to solve regulatory discrepancies through a harmonisation procedure. ${ }^{32}$

The first agreement between the two parties, 'The Transatlantic Declaration on EC-US Relations', was signed in 1990 and was mostly a declaration supporting political cooperation. However it also stated:

\footnotetext{
28 ibid 6-7

29 Vogel (n 3) 22.

30 Alberto Alemanno, 'International Regulatory Cooperation and Its Discontents: What Is Really at Stake in TTIP?' (4 February 2015) <www.sidi-isil.org> accessed 7 December 2015.

31 Tackacs (n 22) 167.

32 Lester and Barbee (n 26) 850.
} 
Both sides recognize the importance of strengthening the multilateral trading system. (...) They will further develop their dialogue, which is already underway, on other matters such as technical and nontariff barriers to industrial and agricultural trade, services, competition policy, transportation policy, standards, telecommunications, high technology and other relevant areas. ${ }^{33}$

This declaration was followed by other instruments which, following the same approach as in 1990, were limited to dialogue mechanisms and were not binding on the regulators. For example, the Trans-Atlantic Business Dialogue (1995) which included CEOs from both sides of the ocean merely formulated common views and positions on technical and sector specific dossiers. While their lobbying activities were sometimes successful, the group was intended to facilitate dialogue rather than to adopt binding decisions. ${ }^{34}$

The most important cooperation mechanism was the adoption of the Mutual Recognition Agreement (MRA) in $1998^{35}$ which aimed at lowering the costs of technical barriers to trade that hindered transatlantic market access in several sectors. Indeed, expectations were high among business and trade policy circles because of the gains that such an agreement could bring. ${ }^{36}$

However, the US-EU MRA suffered from several deficiencies. First, it did not seek full mutual recognition of standards but mutual recognition of inspection, testing and certification requirements which implied that both the US and the EU kept their own domestic standards but allowed both American and European certifiers to assess compliance with both US and EU standards. As a consequence, manufacturers could choose whether to certify their products in one region or the other, which introduced competition between assessors and avoided a double burden on testing and certification. This was a less radical step than a full mutual recognition agreement and therefore it did not alter the role of regulators in the US. ${ }^{37}$

\footnotetext{
33 The Transatlantic Declaration on EC-US Relations (1990), European External Action Service <http://eeas.europa.eu/us/docs/trans_declaration_90_en.pdf> accessed 7 December 2015.

34 Jacques Pelkmans and Anabela Correia de Brito, 'Transatlantic MRAs: Lessons for TTIP?' (2015) 101 CEPS special report.

35 Agreement on Mutual Recognition between the European Community and the United States of America [1999] OJ L3/13.

36 Pelkmans and Correia de Brito (n 34) 1.

37 Charan Devereaux, Robert Z Lawrence and Michael D Watkins (2006) Case Studies in US Trade Negotiation, vol 1, 303-305 < http://www.piie.com/publications/chapters_ preview/392/07iie3624.pdf> accessed 7 December 2015.
} 
Second, the implementation of the agreement happened to be very difficult and in some of the sectors it was completely blocked. ${ }^{38}$ This obstacle can be explained by the significant institutional asymmetries between the two regulatory systems. Indeed, this makes trust, confidence and, thus, regulatory cooperation much more difficult. ${ }^{39}$ For instance, even though an agreement was negotiated in the pharmaceutical sector, no agreement could be reached on the definition of Good Manufacturing Practices, so two different concepts appeared on what was supposed to be one of the essential parts of the MRA in this sector. ${ }^{40}$ In contrast, more symmetries exist as regards telecommunications equipment since both authorities have supported a more decentralised process for pre-marketing approvals and this made the implementation of this annex easier. ${ }^{41}$

Third, this agreement covered only some specific sectors such as telecommunication equipment, pharmaceuticals or medical devices, but cosmetic products were excluded.

As a consequence, it can be said that the MRA of 1998 was the expression of an agreement to disagree, and an illustration that both parties were not ready to negotiate at any cost. However, despite these tensions, this attempt to cooperate made regulatory authorities 'more educated' about each other's systems and led to informal parallel programmes that could have important long-term consequences. ${ }^{42}$

In the cosmetics sector, one of these initiatives has taken place through the International Cooperation on Cosmetics Regulations (ICCR) which is an international group of national regulatory authorities from the United States, Japan, the EU, Brazil and Canada, created in 2007. The ICCR works on recommendations in areas such as allergens, alternatives to animal testing, nanotechnologies or safety assessments. However, the recommendations of that group are considered non-binding on the members and, therefore, once again, have a limited effect on trade.

To conclude, it can be stated that previous attempts to lower regulatory barriers between the EU and the US have adopted the form of nonbinding instruments and the only agreement that has indeed facilitated trade between the two regions has achieved exclusively the mutual recognition of testing and certification requirements in a limited number of areas. This shows that lowering regulatory barriers has not been an un-

\footnotetext{
38 See Pelkmans and Correia de Brito (n 34).

39 Gregory Shaffer, 'Reconciling Trade and Regulatory Goals: The Prospects and Limits of New Approaches to Transatlantic Governance Through Mutual Recognition and Safe Harbor Agreements' (2002) 9 Columbia Journal of European Law 52.

40 Pelkmans and Correia de Brito (n 34) 8.

41 Shaffer (n 39) 52.

42 Shaffer (n 39) 66.
} 
conditional goal so far and that maintaining each regulatory philosophy has prevailed in each of the initiatives undertaken.

\subsection{The EU position on TTIP}

TTIP seems to go one step further than previous forms of cooperation and, therefore, individuals and consumer associations are concerned that this negotiation will have an impact on the regulatory policy of the EU by allowing products that do not meet European high standards in terms of environmental protection and health and consumer safety to be put on the market.

As a result, it is interesting to analyse the EU position paper on TTIP $^{43}$ and to see whether safety standards are more at risk than through previous cooperation mechanisms.

What is striking at first glance is that the most controversial issues have not been included as part of the negotiations. ${ }^{44}$ An example of this is the list of ingredients. Indeed, the first position paper stated that "both parties could explore possibilities for the approximation and mutual recognition of cosmetic ingredients that are allowed in cosmetic products'. As has previously been mentioned, allowed and prohibited ingredients vary substantially in the EU and the US; as a consequence, mutual recognition of ingredients has been heavily criticised. This has had as a consequence the modification of the position paper which now reads as follows: "both parties could endeavour to align their data requirements and scientific safety assessment methods for cosmetic ingredients that must be assessed and authorised for use in cosmetic products'. ${ }^{45}$ The removal of the mutual recognition principle has been very much welcomed by consumer organisations. ${ }^{46}$

On the other hand, some alignment seems to be achievable as regards safety assessments when they are required both in the EU and the US to put a cosmetic product on the market, as is the case with UV filters.

\footnotetext{
43 Commission, DG Trade, 'The Transatlantic Trade and Investment Partnership (TTIP) regulatory Issues: EU Position on Cosmetics - Update' < http://trade.ec.europa.eu/doclib/ docs/2014/may/tradoc_152470.pdf> accessed 7 December 2015.

44 This has been repeated on several occasions by the European Commission. See for instance Cecilia Malström, 'Trade in the $21^{\text {st }}$ Century: The Challenge of Regulatory Convergence' (19 March 2015) <http://trade.ec.europa.eu/doclib/docs/2015/march/tradoc_153260.pdf> accessed 7 December 2015.

45 See the comparison between the two versions published by the Bureau Européen des Unions de Consommateurs <http:/ / beuc.eu/documents/external/EU-position\%20on-cosmetics-comparison-between-2014\%20and-2015\%20versions.pdf > accessed 7 December 2015.

46 Bureau Européen des Unions de Consommateurs, 'The New EU Proposal on Cosmetics: Finally Beyond Lip Service?' (17 March 2015) < http:/ /www.beuc.eu/blog/the-new-eu-proposal-on-cosmetics-finally-beyond-lip-service/> accessed 7 December 2015.
} 
Cooperation can also be achieved in areas where both regions already refer to international standards, for instance concerning Good Manufacturing Practices. Indeed, the European Cosmetics Regulation has already aligned its requirements with the ISO standards which are international standards independent of the EU. In the US, cosmetics must also comply with those standards and therefore convergence on this issue has already taken place. However for OTC drugs, American institutions require different standards, so it could be useful if there were alignment in this area.

Furthermore, the European Commission also mentions the possibility of introducing the principle of mutual recognition for inspection results, which, as has been explained earlier, is something that has already been achieved in other areas, so it could also be done in this one.

As regards animal testing, it has previously been stated that the EU and the US do not share the same values. However, both regions encourage research towards alternatives to animal testing. Therefore, both parties could share knowledge, guidance documents and technical assessments to contribute to new alternative test methods.

Finally, labelling also seems an issue where some convergence could take place, especially as regards trivial names. However, the position paper does not mention the labelling of nanomaterials which is compulsory under the EU Cosmetics Regulation, but not under the FD\&C Act.

These examples show that cooperation could be achieved in noncontroversial areas, but topics like a ban on animal testing, the labelling of nanomaterials, or agreeing on a common list of prohibited ingredients will not in principle be tackled in the negotiations. This seems to predict that no agreement will take place on those issues and therefore both regions will keep their own approach there. Therefore, American undertakings should comply with European safety requirements on those questions and consumer protection would not be undermined.

\section{3 'The Brussels effect':47 an informal mechanism to convergence}

While no real cooperation has been achieved so far in the most controversial issues, it is true that some convergence towards European standards has taken place. Contrary to the belief of some detractors of TTIP, who are concerned about a potential 'race to the bottom' following negotiations with the US, so far American undertakings are the ones having adopted some of the European standards, and not the other way around. ${ }^{48}$

\footnotetext{
47 This heading was taken from Anu Bradford, 'The Brussels Effect' (2012) 107(1) Northwestern University Law Review.

48 Shaffer (n 39) 70.
} 
Indeed, it has been considered that the EU is seeking to be the 'world's economic regulator'. The truth is that the EU has been very successful in exporting its regulations to other countries. This has been the consequence of great efforts from the European institutions to encourage the adoption of European rules abroad and it has been considered that there are mainly three reasons to adopt such a strategy. ${ }^{49}$

First, exporting European rules to other regions of the world imposes the obligation for global competitors of European undertakings to meet similar requirements in their home market ${ }^{50}$ which will, of course, have economic consequences because it will align the costs of production of competitors with those of European manufacturers.

Second, European institutions are also concerned about the legitimacy of their regulations and it is a lot harder to argue that a risk management regime is unnecessary, disproportionate or unfair if it is endorsed by a significant proportion of the world's population'. ${ }^{51}$

Finally, there is a technical reason for this phenomenon as the EU has developed an institutional framework and technical and administrative expertise that make it possible for the institutions to promote global regulatory policy coordination. ${ }^{52}$

On the other hand, it is also useful for other regions to adopt European rules as this gives their manufacturers the possibility to access a very large market which is likely to increase even more in the future. Besides, mutual recognition agreements between the EU and other OECD countries can intensify the pressure on the US because it entails that other countries will adapt their systems to interact with the EU. ${ }^{53}$

Moreover, some firms might actually prefer to adapt their products to the higher standard to convince consumers that their goods are superior and safer and, therefore, to attract more clients. ${ }^{54}$ Hence, adopting European standards in regions where lower requirements exist can actually build a better image of an undertaking as a responsible company which cares about its customers, hence leading to a race to the top. As a result, from the undertaking's point of view, this strategy allows them to sell homogeneous products worldwide and to maintain their reputation.

\footnotetext{
49 Vogel (n 3) 12-13.

50 ibid.

51 Veerle Heyvaert, 'Globalizing Regulation: Reaching Beyond the Borders of Chemical Safety’ (2009) 36(1) Journal of Law and Society 116.

52 Vogel (n 3) 14.

53 Shaffer (n 39) 70.

54 Charan Devereaux, Robert Z Lawrence and Michael D Watkins (2006) 1 Case Studies in US Trade Negotiation, 303 <http://www.piie.com/publications/chapters preview/392/07iie3624.pdf> accessed 7 December 2015.
} 
As a consequence, there is mutual interest that has strengthened 'Europe's unilateral power to regulate global markets'. ${ }^{55}$ This can be observed in the cosmetics sector, among others, in which, as some authors have stated, 'few Americans are aware that EU regulations determine the makeup they apply in the morning'. ${ }^{56}$ Indeed, in this area, Europe has been referred to as the 'undisputed international regulatory hegemon', ${ }^{5}$ and many regions have adopted legislation similar to the European one. Already in the 90s, Mercosur countries adopted the European definition of cosmetics and empowered regulatory agencies to adopt positive and negative lists of ingredients. In 2001, Japan modified its cosmetics legislation and adopted the European model. In 2003, ASEAN adopted legislation that copies the European one and even imports the Annex of the directive containing the positive and negative lists into a binding local regulation. In 2007 China, which is still very far from the European model, banned many substances that were included in the European negative list. ${ }^{58}$

These examples show that major markets are adapting their rules to the European model. This has, for now, not been the case in the US as a whole, but some individual states have followed the same trend. The example broadly stated in the literature is California, which in 2006 adopted legislation based on the European model. ${ }^{59}$

However, the role of the EU as a regulatory model goes even farther by entering the private sphere. Indeed, some private undertakings are adopting voluntary rules in line with European ones even though at a national level the rules that apply to them are less stringent. As the literature has concluded 'these private, market-based forms of "trading-up" have reduced the gap between some European standards and American business practices'. ${ }^{60}$

An example of this voluntary alignment with European standards in the cosmetics sector concerns phthalates. This is an ingredient used in many different cosmetic products such as nail polish, fragrances and shampoos. In 2002, it was decided at the European level that the use of two kinds of phthalates would be prohibited in Europe as of September 2004.

\footnotetext{
55 Bradford (n 47) 3.

56 ibid 3.

57 David Bach and Abraham L Newman, 'Governing Lipitor and Listerine: The Domestic Roots of International Pharmaceutical and Cosmetics Regulation' (2008) IE Business School Working Paper WP08-17, 5.

58 ibid 5-6; Luke Nottage, 'Cosmetics Regulation Under National and ASEAN Law' (University of Sydney -Japanese Law and The Asia-Pacific Blog, 1 June 2015)<http://blogs.usyd. edu.au/japaneselaw/2015/06/cosmetics_regulation.html> accessed 7 December 2015.

59 Vogel (n 3) 15-16.

60 ibid 16.
} 
Nevertheless, in the US the CIR found no evidence that exposure to these ingredients could pose any health risks. Therefore, the official position of the FDA is that there is no risk from the use of cosmetic products containing phthalates'. However, the Campaign for Safe Cosmetics put pressure on cosmetic firms to voluntarily adopt restrictions on their chemical ingredients similar to those required for cosmetics sold in Europe. This was not a complete success, because phthalates continue to be used in many cosmetics in the US, but several manufacturers, among which some of the leading companies of the sector, decided to remove phthalate DBP from their nail products. ${ }^{61}$

\section{If you can't beat them join them: the development of global stand- ards as an alternative to convergence}

\subsection{The establishment of a permanent cooperation mechanism}

According to the previous paragraphs, it seems that no lowering of safety standards will take place upon the negotiation of TTIP since potential negotiations will not tackle the most controversial issues which in any case seem to be converging towards the European model.

However, we can wonder at this stage if this is the only concern about TTIP. On the one hand, it is true that the agreement will not substantially modify the parties' respective ways of making legislation, and their regulatory systems will not be altered in the sense that the EU and the US will not regulate jointly. Indeed, the EU's initial position paper states that 'TTIP provisions shall not affect the ultimate sovereign right of either party to regulate in pursuit of its public policy objectives and shall not be used as a means of lowering the levels of protection provided by either party'. ${ }^{62}$

However, the parties are creating a permanent international regulatory cooperation mechanism and they will establish a 'living agreement' allowing the introduction of new areas of cooperation without reopening the negotiations. ${ }^{63}$ This can be particularly dangerous, taking into account that the agreement should cover existing and proposed regulations. Indeed, the EU position paper on cosmetics states that the EU is seeking further cooperation as regards new issues, with no further expla-

\footnotetext{
61 Vogel (n 3) 214-218.

62 Commission, 'EU-US Transatlantic Trade and Investment Partnership: Trade Crosscutting Disciplines and Institutional Provisions, EU initial position paper' 2, as quoted in Marise Cremona 'Negotiating the Transatlantic Trade and Investment Partnership (TTIP): Context and Scope of TTIP' (2015) 52 Common Market Law Review 353.

63 ibid, 352; Alberto Alemanno, 'International Regulatory Cooperation and its Discontents: What is Really at Stake in TTIP?' (2015) Società Italiana di Diritto Internazionale <http:// www.sidi-isil.org/sidiblog/?p=1303> accessed 7 December 2015.
} 
nation of what this means. Nevertheless, the Commission did add later that this would be a way to coordinate better 'when we make laws in the future'. ${ }^{64}$ This thus entails the risk of pushing 'regulators away from the previously agreed regulatory standards'. ${ }^{65}$

This is not necessarily a bad thing and it could lead to what some authors have called 'hybridisation', which is defined as an 'interactive exchange of ideas, tools and approaches' that 'can contribute to more efficient evolution than purely within system selection pressures would'. ${ }^{66}$ In a model where there is no leader but only followers, the parties are not likely to move towards one or the other set of standards and would rather create a new version quite different from the parental approaches. ${ }^{67}$

This phenomenon seems quite likely in the circumstances of TTIP. Indeed, in a scenario where both parties will be in close cooperation and constantly exchanging information, it is quite realistic to think that they will interact to achieve a common goal.

With a common rival, which is China, the position to be adopted by the EU and the US will probably move beyond simple rivalry and races to the top or the bottom and towards a more complex model which could give rise to a more interesting picture of precaution. ${ }^{68}$

Although this is not per se a negative consequence, the truth is that TTIP will somehow limit the regulatory autonomy of the parties because it will make them aware of the 'extra-territorial impact of their existing and proposed regulations'. ${ }^{69}$ This could lead to regulatory processes going in a different direction than previously, without a proper accountability mechanism to control such change. ${ }^{70}$ Therefore, as the literature has put forward, this cooperation mechanism

requires a degree of trust in the regulatory negotiators of both parties, in particular in their judgement over whether this is a case where the aim of regulatory cooperation should be to find ways of making two very different systems function better together in practice without sacrificing their standards. ${ }^{71}$

\footnotetext{
64 Commission, DG Trade, 'Transatlantic Trade and Investment Partnership: The Regulatory Part' (2013) 3 <http://trade.ec.europa.eu/doclib/docs/2013/july/tradoc_151605. pdf $>$ accessed 7 December 2015.

65 Alemanno (n 63).

66 Wiener (n 7) 270-273.

67 ibid 274.

68 ibid 281.

69 Alberto Alemanno, 'What Is at Stake in TTIP Talks?' (2015) <http://www.albertoalemanno.eu/articles/whatisatstake-inttiptalks $>$ accessed 7 December 2015.

70 ibid.

71 Cremona (n 62) 353.
} 


\subsection{Pursuing the maintenance of regulatory hegemony?}

Another outcome of the negotiations between the EU and the US refers to the maintenance of regulatory hegemony. As this article has previously explained, the EU can be considered a regulatory hegemon in many different sectors, among which is the cosmetics one.

Therefore, it can be predicted that the EU is negotiating deep and comprehensive free trade agreements with several countries to promote the European approach to regulation and enhance its leadership position. This has been observed with some partners such as Ukraine where the agreement included a large part of the acquis communautaire.

With other countries, such as the US, this is more difficult to achieve because of its very different regulatory approach and its economic weight. As an alternative strategy, the EU is 'seeking to enlist the USA as a collaborative partner in promoting and improving international standards', with the TTIP functioning as an example to other systems which could shape global regulations and standards in the near future. ${ }^{72}$ Following this approach, it can be stated that the aim of TTIP is not (only) to converge towards American or European standards in a range of regulatory issues; instead, the goal would be to develop, update and implement international standards so that other regions in the world also adopt them. ${ }^{73}$

According to this perspective, the EU would not only be seeking to increase trade with the US; instead, it would also be trying to maintain its regulatory leadership by collaborating with the US rather than by competing with it. This has been stated very recently by the negotiators who acknowledged that 'agreeing rules on certain areas could help us project our shared values more globally and contribute, to the extent possible, to the development of future global rules and standards'. ${ }^{74}$

\section{Conclusion}

To conclude, it can be stated that regulatory cooperation between the EU and the US seems to be largely justified when the differences in legislation are analysed and taking into account the strong trade relationship that characterises the two regions. However, two distinctive regulatory approaches and philosophies exist across the Atlantic and the parties are not ready to increase trade at any cost. Indeed, previous at-

\footnotetext{
72 ibid 355

73 ibid.

74 TTIP Round 8, Comments by EU Chief Negotiator Ignacio García Bercero (Brussels 2015) 3 <http://trade.ec.europa.eu/doclib/docs/2015/february/tradoc_153110.pdf> accessed 7 December 2015.
} 
tempts to cooperate, as well as the current EU position paper on TTIP concerning cosmetic products, underline that the parties are not seeking to cooperate in very controversial areas such as animal testing, prohibited ingredients or nanotechnology.

Although from a regulatory perspective public authorities have not adopted common standards balancing safety and innovation, the need to trade in both regions has broadened the range of actors involved, from states to agencies and private undertakings. As this article has pointed out, companies established in the US seem to be increasingly risk-averse which could lead to a de facto adoption of European standards. Therefore, convergence would be taking place voluntarily rather than through TTIP.

However, TTIP has made apparent that the parties are willing to strengthen the dialogue between regulatory institutions to develop global standards in order to counterbalance the growing power of emerging economies. From this perspective, instead of formal convergence there would be a permanent exchange of ideas that could modify the way in which domestic regulation takes place. 